\title{
Microsatellite Instability in Greek Colorectal Carcinoma Patients: Clinicopathological and Molecular Correlations
}

\author{
PATROKLOS KATAFYGIOTIS*, STRATIGOULA SAKELLARIOU*, ILENIA CHATZIANDREOU, \\ IOANNA GIANNOPOULOU, IRENE THYMARA, ANGELICA A. SAETTA ${ }^{\#}$ and PENELOPE KORKOLOPOULOU ${ }^{\#}$
}

First Department of Pathology, Medical School, National and Kapodistrian University of Athens, Athens, Greece

\begin{abstract}
Background/Aim: In the present retrospective study, we assessed the molecular profile and clinicopathological correlations of Greek colorectal carcinoma (CRC) patients. Patients and Methods: Data from 157 CRC patients were collected. High Resolution Melting Analysis and Pyrosequencing/Sanger sequencing were applied to identify KRAS, BRAF, NRAS mutations and microsatellite instability (MSI) status. Immunohistochemistry was performed to characterize the associated Mismatch Repair Protein loss. Statistical calculations were performed using the statistical package SPSS v21.0. Results: KRAS mutations were detected in $39.3 \%$ of cases, BRAF in $10.9 \%$ and NRAS in $4.9 \%$. MSI status was recognized in $11.5 \%$ of CRC patients and was associated with right colon tumors. MSI phenotype was inversely correlated with stage, $N$ status and KRAS mutations and positively correlated with BRAF mutations. Conclusion: MSI positive CRCs in the Greek population are more often right-sided, free of metastasis, KRAS wild type and BRAF mutated. Providing more detailed clinicopathological and molecular data for specific populations will enable better clinical management and individualized therapy in the future.

Colorectal cancer (CRC) is the third most commonly diagnosed cancer in the Western world $(1,2)$ and remains one of the leading causes of death worldwide. The incidence of CRC in younger population ( $<50$ years of age) has increased, despite the fact that during the previous decade a
\end{abstract}

\footnotetext{
*These Authors contributed equally to this work.

\#These Authors contributed equally to this work.

Correspondence to: Patroklos Katafygiotis, 1st Department of Pathology, National and Kapodistrian University of Athens, Athens, Greece. E-mail: patlamkat@yahoo.gr

Key Words: Colorectal Cancer, MSI, KRAS, NRAS, BRAF mutations.
}

decline by $3 \%$ per year has been observed in the general population, mainly due to the decrease of recto-sigmoid tumours (3). Reports from a variety of countries and ethnicities suggest that population and regional characteristics such as local environment and life habits may contribute to the development and course of CRC. According to the latest Eurostat report in July 2018, CRC deaths in the European Union (EU) accounted for $11.3 \%$ of all deaths from cancer and $3 \%$ of the total number of deaths, irrespective of cause. Among 28 member states, the proportion of CRC deaths varied from $4 \%$ (Croatia) to $2.3 \%$ (Greece, Finland and Bulgaria).

The pathogenetic basis of CRC is a combination of various somatic and germline mutations as well as epigenetic alterations. The activation of oncogenes such as $B R A F, K R A S$, $N R A S$ and the inactivation of tumour suppressor genes by hypermethylation of $\mathrm{CpG}$ islands in the methylator phenotype (CIMP) constitute distinct pathways underpinning the development of CRC. Gene mutations have been widely studied in CRC Western populations (US and EU) as well as in some Eastern populations (China and Korea). The frequency of microsatellite instability (MSI) was approximately $15-20 \%$ in the Western populations (4-9) and 9.6-13\% in the Eastern populations (10-14). KRAS mutations are considered the most frequent molecular alteration in colon cancer with a range of $22-46.7 \%$ in Western populations (5, $6,15-18$ ) and $19.7-43.9 \%$ in the Chinese population. Moreover, the frequency of $B R A F$ mutations ranges from 5 to $21.8 \%$ in Western populations $(15,19-23)$ and from 1.7 to $25.4 \%$ in the Chinese population (24-30). NRAS mutations occur rarely in CRC with a frequency of $2.2 \%$ in the West (31) and up to $3.4 \%$ in China (32).

In the era of personalized medicine, tumour molecular characteristics determine prognosis and guide treatment of cancer patients. Testing CRC tumour tissue for MSI phenotype, KRAS and BRAF mutations has been suggested in a routine clinical setting since 2010 (33). Patients in early stage who are DNA mismatch repair deficient (dMMR) have a favorable prognosis, with longer disease-free survival 
(DFS) and overall survival (OS) (34-38). Concerning chemotherapy, MSI has been the target of different therapeutic protocols due to the poor benefit of MSI positive CRC patients from chemotherapeutics such as pyrimidine analogues (cisplatin, temozolomide and procarbazine) and fluorouracil-based adjuvant chemotherapy (34, 35, 39). Clinical trials have shown that CRC patients with KRAS mutations fail to respond sufficiently to anti-epidermal growth factor receptor (EGFR) agents, a major therapeutic target for CRC, exhibiting additionally serious side effects (40-46). Consequently, at present, testing of KRAS mutations is imperative for the proper treatment of CRC patients. Recently, the MSI status has been linked to antiPD1 therapy $(47,48)$. Moreover, $B R A F$ mutations are considered a poor prognostic factor because of their higher incidence in patients with metastatic disease and advanced TNM stage (19).

In the present retrospective study, we gathered data from 157 CRC Greek patients from the pathology database of our Department (First Department of Pathology, University of Athens), a referral laboratory performing diagnosis, consultation and molecular analysis. The purpose of the study was to assess the frequency of MSI phenotype, $K R A S$, $N R A S$ and BRAF mutations in the Greek population and examine possible intra-racial differences based on origin, considering that geographical and ethnic differences in molecular profile should be taken into account in the prognostic and therapeutic approach of patients with CRC.

\section{Patients and Methods}

Ethics statement. The present study was approved by the University of Athens Ethics Committee (Protocol No. ES1106/212-10-02). Since this was a retrospective study, the Ethics Committee waived the need for an informed consent, and a policy of strict anonymity and confidentiality was adopted. All patient data were anonymized and de-identified in a confidential manner. All information included in the data set was used exclusively for the purpose of this study, and was not shared with other individuals or organizations. Consecutive cases with available material in the First Department of Pathology, University of Athens Medical School, Greece database were included.

Patients. Data were collected from 157 patients, $60.5 \%$ males and $39.5 \%$ females (males $=95$, females $=62$, median age $=67$ years; range $=34-89$ years), for whom archival material was available in our Department. The cohort included patients with either primary (right colon $29.3 \%$, left colon $5.7 \%$, rectosigmoid $37 \%$ ) or metastatic CRC $(28 \%)$ in liver, lung or lymph nodes. The distribution according the 8th edition of CRC staging was as follows: $8.9 \%$ stage I, $40.8 \%$ stage II, $22.3 \%$ stage III, $28 \%$ stage IV.

Genomic DNA isolation. DNA was extracted from formalin fixed paraffin embedded tissues. Ten $\mu \mathrm{m}$ thick sections were cut from tissue blocks after macrodissection under the light microscope. DNA was extracted from the selected tissue areas following a standard DNA extraction kit protocol (NucleoSpin tissue, Macherey-Nagel, Duren, Germany). The concentration of the extracted DNA was measured using a Nanodrop Microliter spectrophotometer.

Molecular analysis. In order to examine the mutational profile of the patients, as far as the MAPK signaling pathway is concerned, High Resolution Melting Analysis (HRMA) on a Light Cycler 480 (Roche Diagnostics, GmbH, Mannheim, Germany) in duplicate. Pyrosequencing/sanger sequencing were applied to confirm mutations in KRAS/NRAS (exons 2,3,4), and BRAF (exon 15).

HRMA: Each PCR reaction consisted of $20 \mathrm{ng}$ DNA, $0.3 \mu \mathrm{M}$ of each primer, $10 \mu \mathrm{l}$ LightCycler 480 HRM Master Mix (Roche Diagnostics, GmbH, Mannheim, Germany), $3.5 \mathrm{mM} \mathrm{MgCl}_{2}$ in a total volume of $20 \mu \mathrm{l}$. The thermal profile used in the Light Cycler was: $95^{\circ} \mathrm{C}$ for $10 \mathrm{~min}$, followed by 50 cycles at $95^{\circ} \mathrm{C}$ for $10 \mathrm{sec}$, with annealing temperatures at $56^{\circ} \mathrm{C}-K R A S, 60^{\circ} \mathrm{C}-B R A F$, $64^{\circ} \mathrm{C}-N R A S$ for $15 \mathrm{sec}$, and a final extension stem at $72^{\circ} \mathrm{C}$ for 7 sec. The sequences of the primers for $B R A F, K R A S$ have been published previously (49). For MSI status, a panel of mononucleotide microsatellite markers (BAT25, BAT26, NR21, NR24) was analysed by HRM analysis, performed as reported previously $(50,51)$.

Pyrosequencing/Sequencing: Alterations in KRAS exons 2, 3, 4, NRAS exons 2, 3 and BRAF exon 15 observed by HRMA, were confirmed by Pyrosequencing using the Pyromark Gold Q24 Reagent kit with the Q24 Pyrosequencer (Qiagen GmbH, Hilden, Germany) according to the manufacturer's protocol. Sanger Sequencing was used to confirm mutations in $B R A F$ (except codon 600 ) and in exon 4 of NRAS. Briefly, PCR products positive by HRMA were sequenced using the BigDye terminator cycle sequencing kit (Applied Biosystems, CA, USA) in order to confirm the presence of mutations. The sequencing products were analysed on an ABI Prism 310 Genetic Analyzer (Applied Biosystems). PCR primers were also used for sequencing analysis.

Immunohistochemistry. Immunohistochemistry for Mismatch Repair (MMR) proteins was performed on $4 \mu \mathrm{m}$ formalin-fixed paraffin embedded tissue sections from 18 patients with MSI molecular phenotype in order to identify the associated protein loss. Detection of MMR proteins was performed using the Leica Polymer Refine Detection kit on a Leica Bond-III Automated Immunohistochemistry stainer (Leica Biosystems Newcastle Ltd, Newcastle, UK). The antibodies applied were MLH1 (clone ESO5, Leica), PMS2 (clone MOR4G, Leica), MSH2 (clone 25D12, Leica) and MSH6 (clone PU29, Leica), at dilutions 1:90, 1:50, Ready to use and 1:300, respectively.

Normal colonic crypt epithelium, lymphocytes and other stromal cells adjacent to cancer cells served as internal positive control. Tumour was defined as deficient when tumour cells showed complete absence of nuclear staining in contrast to non-neoplastic cells which maintained nuclear protein expression, and intact, if tumour cells showed nuclear positivity.

Statistical analysis. Statistical analysis was performed in order to correlate MSI status with mutational status and other parameters such as gender, histological grade, stage etc., using Pearson's Chi square and Fisher's exact test where appropriate. Age groups were divided into two categories, above and below the median age. Statistical calculations were performed using the statistical package 
Table I. Clinicopathological data of studied CRC patients.

\begin{tabular}{|c|c|c|}
\hline Characteristics & Number (n) & Percentage $(\%)$ \\
\hline \multicolumn{3}{|l|}{ Gender } \\
\hline Male & 95 & $60.5 \%$ \\
\hline Female & 62 & $39.5 \%$ \\
\hline \multicolumn{3}{|l|}{ Location } \\
\hline Right colon & 46 & $29.3 \%$ \\
\hline Left colon & 9 & $5.7 \%$ \\
\hline Rectosigmoid & 58 & $37 \%$ \\
\hline Metastasis & 44 & $28 \%$ \\
\hline \multicolumn{3}{|l|}{ Tumour grade } \\
\hline G1 & 3 & $1.9 \%$ \\
\hline $\mathrm{G} 2$ & 103 & $65.6 \%$ \\
\hline G3 & 51 & $32.5 \%$ \\
\hline \multicolumn{3}{|l|}{ Tumour stage } \\
\hline I & 14 & $8.9 \%$ \\
\hline II & 64 & $40.8 \%$ \\
\hline III & 35 & $22.3 \%$ \\
\hline IV & 44 & $28 \%$ \\
\hline \multicolumn{3}{|c|}{ Vascular/lymphatic invasion } \\
\hline Presence & 41 & $29.7 \%$ \\
\hline Absence & 97 & $70.3 \%$ \\
\hline N/A & 19 & \\
\hline \multicolumn{3}{|c|}{$\begin{array}{l}\text { Tumour-infiltrating } \\
\text { lymphocytes (TILS) }\end{array}$} \\
\hline Presence & 101 & $72.7 \%$ \\
\hline Absence & 38 & $27.3 \%$ \\
\hline N/A & 18 & \\
\hline \multicolumn{3}{|l|}{ Ulceration } \\
\hline Presence & 82 & $59 \%$ \\
\hline Absence & 57 & $41 \%$ \\
\hline N/A & 18 & \\
\hline \multicolumn{3}{|c|}{ Desmoplastic stromal reaction } \\
\hline Presence & 95 & $68.3 \%$ \\
\hline Absence & 44 & $31.7 \%$ \\
\hline $\mathrm{N} / \mathrm{A}$ & 18 & \\
\hline \multicolumn{3}{|c|}{$\begin{array}{l}\text { Tumour growth on a preexisting } \\
\text { adenomatous polyp }\end{array}$} \\
\hline Yes & 21 & $13.5 \%$ \\
\hline No & 135 & $86.5 \%$ \\
\hline N/A & 1 & \\
\hline \multicolumn{3}{|l|}{ Necrosis } \\
\hline Yes & 50 & $36 \%$ \\
\hline No & 89 & $64 \%$ \\
\hline N/A & 18 & \\
\hline
\end{tabular}

N/A: Not available.

SPSS v21.0 for Windows. All results with a two-sided $p$-value $<0.05$ were considered significant. Associations of mutational status with TNM stage were limited to surgical samples.

\section{Results}

Patient characteristics. The following clinicopathological features were available for statistical analysis: patients' age, gender, tumour stage defined as early (stage I and II) and
Table II. Alterations in KRAS, BRAF, NRAS genes and MSI status.

\begin{tabular}{lcc}
\hline Molecular analysis & Number (n) & Percent (\%) \\
\hline MSI status & & \\
MSI & 18 & $11.5 \%$ \\
MSS & 139 & $88.5 \%$ \\
KRAS & & \\
Wild type & 88 & $60.7 \%$ \\
Mutant & 57 & $39.3 \%$ \\
N/A & 12 & \\
NRAS & & \\
Wild type & 137 & $95.1 \%$ \\
Mutant & 7 & $4.9 \%$ \\
N/A & 13 & \\
BRAF & & \\
Wild type & 131 & $89.1 \%$ \\
Mutant & 16 & $10.9 \%$ \\
N/A & 10 & \\
\hline
\end{tabular}

N/A: Not available.

advanced (stage III and IV), pTNM classification based on the 8th edition of American Joint Committee on Cancer (AJCC), histological tumour grade, tumour location (right, left colon, rectosigmoid), vascular/lymphatic invasion, necrosis, presence of tumour-infiltrating lymphocytes (TILS), ulceration, desmoplastic stromal reaction and tumour growth on a preexisting adenomatous polyp. Clinicopathological data of all studied CRC patients are summarized in Table I.

Alterations in KRAS, BRAF, NRAS genes and MSI status. KRAS mutational analysis was performed in 145 samples of which $39.3 \%$ (57/145) were mutated (Table II, Figure 1). KRAS mutations affected mainly codon $12(40.4 \%)$ and the most frequent mutations were p.Gly12Asp (21\% of mutant cases) and p.Gly13Asp (17.5\%). In particular, nine different mutations were identified, five of which at codon 12: p.Gly12Asp, p.Gly12Cys, p.Gly12Val, p.Gly12Ala, p.Gly12Ser, one at codon 13 (p.Gly13Asp), two at codon 61 of exon 3 (p.Glu62Gln, p.Glu61Lys) and one at codon 146 of exon 4 (p.Ala146Thr). Analysis of BRAF gene exon 15 (activation segment) revealed mutations in $10.9 \%$ of the cases (16 out of 147) all identified as $\mathrm{T}$ to $\mathrm{A}$ transitions at nucleotide 1799 causing substitution of Valine by Glutamine at codon 600, (p.Val600Glu) (Table II, Figure 1). NRAS mutations were found in $4.9 \%$ of the samples ( 7 out of 144) and were identified as p.Gly12Val in exon 2 and p.Ala59Thr, p.Gln61Leu, p.Gln61 Arg in exon 3 (Table II, Figure 1).

Microsatellite instability status was detected in $11.5 \%$ (18 out of 157 cases) in our cohort (Table II). These cases were further confirmed by immunohistochemistry for MMR proteins; 17 cases displayed MLH1/PMS2 loss and 1 case showed MSH2/MSH6 loss. 


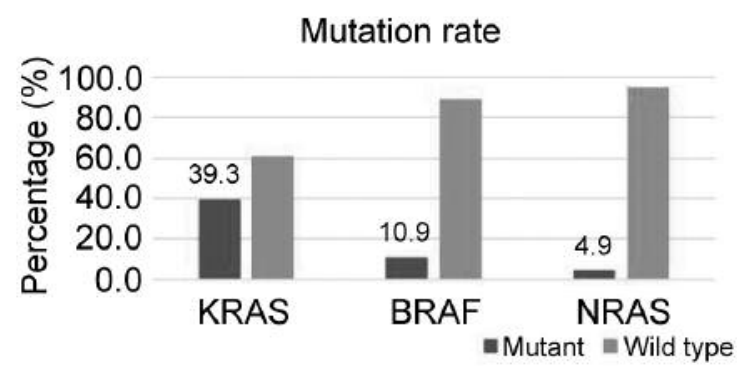

Figure 1. KRAS, BRAF and NRAS mutational analysis.

Correlations among various clinicopathological parameters. Male patients presented CRC at a younger age ( $<67$ years) compared to female patients $(p=0.021)$. In addition, tumours arose on a preexisting adenomatous polyp more often in females than in males $(p=0.001)$. Desmoplastic stromal reaction was significantly more frequently observed in males compared to female patients $(p=0.007)$ and was associated with the presence of TILS $(p<0.0001)$.

We found a correlation between vascular/lymphatic invasion and stage of disease. Vascular or lymphatic invasion was more frequently found in advanced disease stage compared to early stage $(p=0.001)$. Necrosis was present at higher percentage in advanced stage tumours than at early stage tumours $(p=0.034)$. A positive correlation was also seen between necrosis and the presence of vascular /lymphatic invasion $(p=0.001)$. Moreover, vascular/lymphatic invasion was found at a higher rate in grade 3 tumours than in grade $1 \& 2$ tumours $(p=0.003)$. Grade was marginally positively associated with stage $(p=0.060)$ and negatively associated with the presence of TILs $(p=0.029)$.

Correlation of MSI status with clinicopathological parameters. MSI status was inversely correlated with stage $(p=0.002)$. In particular, early stage tumours showed MSI at a frequency of $19.2 \%$ (15 out of 78 stage I\&II) compared to advanced stage tumours (MSI 9.1\%, 3 out of 79 stage III\&IV). MSI status was related to tumour location; patients who displayed MSI tended to present with tumours in the right colon $(p<0.0001)$. Furthermore, MSI status was negatively associated with $\mathrm{N}$ status $(p=0.043)$.

Correlation of MSI with molecular alterations. MSI tumours were positively correlated with $B R A F(p<0.0001)$, (Figure 2a) and negatively correlated with KRAS mutations $(p<0.006)$ (Figure 2b).

Correlation of molecular alterations (KRAS/NRAS, BRAF mutations) with clinicopathological features. Tumours growing on a preexisting adenomatous polyp displayed
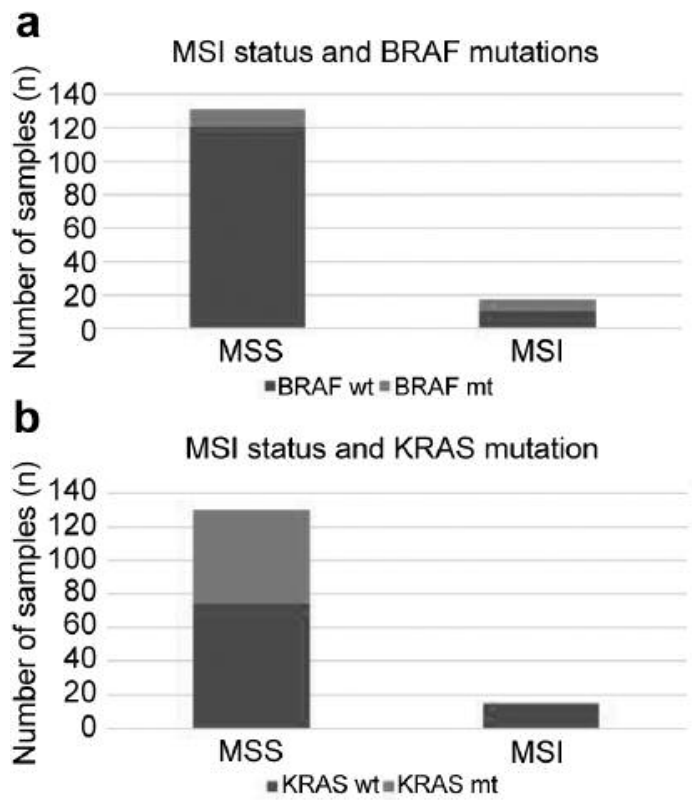

Figure 2. Correlation of MSI with a) BRAF and b) KRAS.

KRAS mutations at higher frequency $(p=0.012)$. KRAS and $B R A F$ mutations were mutually exclusive $(p=0.001)$. Finally, $B R A F$ mutations were more frequently encountered in tumours arising in the right colon $(p=0.020)$.

\section{Discussion}

In the present study, several clinicopathological features of colon cancer patients of Greek origin were analysed. In particular, our study addressed the characteristics of Greek CRC patients including gender, age, pathological grade and stage, location of the tumour, KRAS, NRAS, BRAF gene mutations, the presence of MSI, and other histological findings.

CRC patients younger than 67 years of age tended to be more often males than females. Gender differences with regard to CRC incidence diminished among older patients. Similar results have been presented by Abotchie et al. who investigated 373.956 patients and showed that CRC incidence was higher in men than women, particularly in patients below 60 years of age (52).

Our findings do not support gender and age differences among Greek CRC patients concerning KRAS, BRAF mutations and MSI phenotype. This is in agreement with reports on American and European (Netherlands) patients that did not observe statistically significant relationships between KRAS mutations and gender or age $(53,54)$. However, four different research groups studying Chinese patients found an association between KRAS mutations and gender, but not age $(26,28)$, while Gao et al. have observed 
associations between KRAS mutations and gender, age as well as tumour differentiation (55). Concerning $B R A F$ mutations and MSI phenotype, our results are in disagreement with previous studies that detected MSI and $B R A F$ mutations more frequently in females and older CRC patients $(19,56-58)$.

In our study, KRAS mutation rate was $39.3 \%$ similar to that reported in other ethnic groups such as Swiss, Spanish, Czech, British, Chinese, Russian, and US populations (6, 15$18,28,53,55,59,60-67)$. No association between metastatic CRC and KRAS mutations was determined in the present study. This finding is in accordance with the current treatment strategy which excludes anti-EGFR agents in Stage IV patients with KRAS mutated CRC (68).

In the present cohort, KRAS mutations did not differ between tissue samples from various metastatic sites Additionally, KRAS mutant tumours in Greek CRC female patients showed a statistically significant association with a preexisting adenomatous polyp. Interestingly this association was not demonstrated in the male population. Upon review of the pathology reports, it was not clear whether these patients had a prior colonoscopy with or without polypectomy. In the female group, our results are in accordance with the findings of two studies, one from Spain and the other from the UK, where adenomatous polyps with $K R A S$ mutations showed an increased risk of developing advanced neoplasia $(69,70)$.

$K R A S$ and BRAF mutations in CRC patients were found to be mutually exclusive in this and many other studies from different countries $(15,59,71,72)$, whereas a single survey carried out in Chinese patients has reported the coexistence of KRAS and BRAF mutations in $24 \%$ of cases (57).

$B R A F$ mutation rate in our CRC series was $10.9 \%$, significantly different from that recorded in studies from Russia (4.1\%), Japan (3\%), Israel (5\%) and China (7\%); albeit comparable to that reported in studies from the USA and Europe $(5,6,22,28-30,65,72-74)$. We suggest that there are considerable ethnic variations regarding $B R A F$ mutations. BRAF mutations have also been associated with the location of the tumour, showing increased frequency in right-sided tumours, in accordance with previous reports (19, 71). Additionally, MSI tumours were positively correlated with $B R A F$ mutations. In the recent literature, $B R A F$ mutations have been associated with sporadic MSI CRC, occurring rarely in Hereditary non-polyposis colorectal cancer (HNPCC) - Lynch Syndrome $(75,76)$.

In the present report, a strong negative correlation between MSI and lymph node metastasis emerged as the vast majority of patients who had MSI did not exhibit lymph node metastasis. The correlation between MSI and DFS, OS and lymph node involvement has been evaluated in previous studies showing that a higher number of negative lymph nodes is associated with MSI positive status (77). MSI positive early stage CRCs demonstrate a more favorable prognosis (78-82). It is hypothesized that this occurs due to an increased immune response regarding these tumours (82). MSI positive CRCs have distinctive clinicopathological characteristics compared to MSI negative ones. In our analysis, the frequency of MSI positivity rose to $11.5 \%$. In other Western countries, this frequency ranges from 15 to $20 \%(5-8,17,34,39)$. In the Chinese population, the frequencies of MSI positive CRCs, displaying at least two or more microsatellite markers, was $11.9-13 \%(5-9,15,20)$. The same reports have shown that MSI positive tumours were more commonly seen in Stage II rather than Stage III disease. We found a similar correlation of MSI with stage in the Greek population so that early stage (I/II) tumours were more often MSI positive than late stage (III/IV) ones (19.2\% vs. 9\%).

The current study analysed the largest series of Greek CRC patients with regard to MSI status by molecular testing which is the direct proof of MSI in the tumour sample. We also performed MMR immunohistochemistry in MSI positive patients to identify the specific gene responsible for mismatch deficiency through protein loss (83). MSI positive CRCs in our samples had a strong correlation with right colon location, while $77.8 \%$ of MSI positive CRCs had a right colon location in concordance with most previous investigations (84). In these studies, tumours with increased TILs had MSI positive status suggesting that MSI could lead to the formation of new epitopes responsible for the upregulation of the immune response. This is the explanation for the recent use of PD-1 inhibitors in MSI positive CRCs (47).

In conclusion, the present study demonstrated the frequency of MSI, KRAS, NRAS, BRAF molecular markers in the Greek CRC patients. In Greece, as well as in other countries, male patients show an earlier onset of disease in comparison to female patients. MSI positive tumours were more often right colon located, free of metastasis, KRAS wild type and $B R A F$ mutated. Additional epidemiological data should be evaluated in order to establish the geographic and ethnic variability in patients with CRC. Providing more detailed clinicopathological and molecular data for specific populations may facilitate their clinical management and individualized therapy in the future.

\section{Conflicts of Interest}

The Authors of this study have no conflicts of interest to declare.

\section{Authors' Contributions}

P Korkolopoulou coordinated the present study and edited the manuscript to be submitted. AA Saetta conceived the idea, planned the molecular analysis, interpreted the molecular data and supervised the molecular findings of this work. I Thymara commented on the manuscript. I Giannopoulou carried out the immunohistochemical analyses, interpreted the immunohistochemical results, wrote the 
related part and commented on the manuscript. I Chatziandreou carried out the molecular and statistical analyses of the data, performed the experiments, contributed in writing the description of the methods and designed the figures. S Sakellariou worked on the manuscript critically for important intellectual content and helped in the sequence alignment of the text as well as the verification of the results. P Katafygiotis conceived the study, reviewed the literature, collected the clinical and the experimental data and wrote the manuscript.

\section{References}

1 American Cancer Society: Cancer facts and figures 2010. Atlanta: American Cancer Society, 2010.

2 National Cancer Institute: Surveillance, Epidemiology, and End Results (SEER). Available at: seer.cancer.gov/ (Last accessed February 25, 2011).

3 Siegel R, Desantis C and Jemal A: Colorectal cancer statistics, 2014. CA Cancer J Clin 64: 104-117, 2014. PMID: 24639052. DOI: $10.3322 /$ caac. 21220

4 Vasovcak P, Pavlikova K, Sedlacek Z, Skapa P, Kouda M, Hoch $\mathrm{J}$ and Krepelova A: Molecular genetic analysis of 103 sporadic colorectal tumours in Czech patients. PLoS One 6: e24114, 2011. PMID: 21901162. DOI: 10.1371/journal.pone.0024114

5 Naguib A, Mitrou PN, Gay LJ, Cooke JC, Luben RN, Ball RY, McTaggart A, Arends MJ and Rodwell SA: Dietary, lifestyle and clinicopathological factors associated with BRAF and K-ras mutations arising in distinct subsets of colorectal cancers in the EPIC Norfolk study. BMC Cancer 10: 99, 2010. PMID: 20233436. DOI: $10.1186 / 1471-2407-10-99$

6 Zlobec I, Bihl MP, Schwarb H, Terracciano L and Lugli A: Clinicopathological and protein characterization of BRAF- and K-RAS mutated colorectal cancer and implications for prognosis. Int J Cancer 127: 367-380, 2010. PMID: 19908233. DOI: $10.1002 /$ ijc. 25042

7 Kim GP, Colangelo LH, Wieand HS, Paik S, Kirsch IR, Wolmark $\mathrm{N}$ and Allegra CJ: Prognostic and predictive roles of high-degree microsatellite instability in colon cancer: A National Cancer Institute-National Surgical Adjuvant Breast and Bowel Project Collaborative Study. J Clin Oncol 25: 767-772, 2007. PMID: 17228023. DOI: 10.1200/jco.2006.05.8172

8 Sinicrope FA, Foster NR, Yoon HH, Smyrk TC, Kim GP, Allegra CJ, Yothers G, Nikcevich DA and Sargent DJ: Association of obesity with DNA mismatch repair status and clinical outcome in patients with stage II or III colon carcinoma participating in NCCTG and NSABP adjuvant chemotherapy trials. J Clin Oncol 30: 406-412, 2012. PMID: 22203756. DOI: 10.1200/jco.2011.39.2563

9 Sinicrope FA, Foster NR, Thibodeau SN, Marsoni S, Monges G, Labianca R, Kim GP, Yothers G, Allegra C, Moore MJ, Gallinger S and Sargent DJ: DNA mismatch repair status and colon cancer recurrence and survival in clinical trials of 5fluorouracil-based adjuvant therapy. J Natl Cancer Inst 103: 863875, 2011. PMID: 21597022. DOI: 10.1093/jnci/djr153

10 Huang YQ, Yuan Y, Ge WT, Hu HG, Zhang SZ and Zheng S: Comparative features of colorectal and gastric cancers with microsatellite instability in Chinese patients. J Zhejiang Univ Sci B 11: 647-653, 2010. PMID: 20803768. DOI: 10.1631/ jzus.B1000198

11 Jin HY, Liu X, Li VK, Ding Y, Yang B, Geng J, Lai R, Ding S, Ni M and Zhao R: Detection of mismatch repair gene germline mutation carrier among Chinese population with colorectal cancer. BMC Cancer 8: 44, 2008. PMID: 18257912. DOI: 10.1186/1471-2407-8-44

12 Jeon CH, Lee HI, Shin IH and Park JW: Genetic alterations of APC, K-ras, p53, MSI, and MAGE in Korean colorectal cancer patients. Int J Colorectal Dis 23: 29-35, 2008. PMID: 17704924. DOI: $10.1007 / \mathrm{s} 00384-007-0373-0$

13 Jung SB, Lee HI, Oh HK, Shin IH and Jeon CH: Clinicopathologic parameters for prediction of microsatellite instability in colorectal cancer. Cancer Res Treat 44: 179-186, 2012. PMID: 23091444. DOI: $10.4143 /$ crt.2012.44.3.179

14 Xiao XY, Zhou XY, Sun MH, Yan G and Du X: Microsatellite instability of sporadic colorectal carcinomas and its clinicopathological significance. Zhonghua Zhong Liu Za Zhi 28: 289-293, 2006. PMID: 16875631.

15 Roth AD, Tejpar S, Delorenzi M, Yan P, Fiocca R, Klingbiel D, Dietrich D, Biesmans B, Bodoky G, Barone C, Aranda E, Nordlinger B, Cisar L, Labianca R, Cunningham D, Van Cutsem $\mathrm{E}$ and Bosman F: Prognostic role of KRAS and BRAF in stage II and III resected colon cancer: results of the translational study on the PETACC-3, EORTC 40993, SAKK 60-00 trial. J Clin Oncol 28: 466-474, 2010. PMID: 20008640. DOI: 10.1200/ jco.2009.23.3452

16 Pérez-Ruiz E, Rueda A, Pereda T, Alcaide J, Bautista D, Rivas Ruiz F, Villatoro R, Pérez D and Redondo M: Involvement of KRAS mutations and amino acid substitutions in the survival of metastatic colorectal cancer patients. Tumour Biol 33: 1829-1835, 2012. PMID: 22791568. DOI: 10.1007/s13277-012-0442-Z

17 Vasovcak P, Pavlikova K, Sedlacek Z, Skapa P, Kouda M, Hoch $\mathrm{J}$ and Krepelova A: Molecular genetic analysis of 103 sporadic colorectal tumours in Czech patients. PLoS One 6: e24114, 2011. PMID: 21901162. DOI: 10.1371/journal.pone.0024114

18 Cunningham D, Atkin W, Lenz HJ, Lynch HT, Minsky B, Nordlinger B, Starling N: Colorectal cancer. Lancet 375: 10301047, 2010. PMID: 20304247. DOI: 10.1016/s0140-6736(10) 60353-4

19 Chen D, Huang JF, Liu K, Zhang LQ, Yang Z, Chuai ZR, Wang YX, Shi DC, Huang Q and Fu WL: BRAFV600E mutation and its association with clinicopathological features of colorectal cancer: a systematic review and meta-analysis. PLoS One 9: e90607, 2014. PMID: 24594804. DOI: 10.1371/journal.pone.0090607

20 Tie J, Gibbs P, Lipton L, Christie M, Jorissen RN, Burgess AW, Croxford M, Jones I, Langland R, Kosmider S, McKay D, Bollag G, Nolop K, Sieber OM and Desai J: Optimizing targeted therapeutic development: analysis of a colorectal cancer patient population with the BRAF(V600E) mutation. Int J Cancer 128: 2075-2084, 2011. PMID: 20635392. DOI: 10.1002/ijc.25555

21 Shaukat A, Arain M, Thaygarajan B, Bond JH and Sawhney M: Is BRAF mutation associated with interval colorectal cancers? Dig Dis Sci 55: 2352-2356, 2010. PMID: 20300843. DOI: 10.1007/ s10620-010-1182-9

22 Rozek LS, Herron CM, Greenson JK, Moreno V, Capella G, Rennert $G$ and Gruber SB: Smoking, gender, and ethnicity predict somatic BRAF mutations in colorectal cancer. Cancer Epidemiol Biomarkers Prev 19: 838-843, 2010. PMID: 20200438. DOI: 10.1158/1055-9965.epi-09-1112

23 Phipps AI, Buchanan DD, Makar KW, Burnett-Hartman AN, Coghill AE, Passarelli MN, Baron JA, Ahnen DJ, Win AK, Potter JD and Newcomb PA: BRAF mutation status and survival after colorectal cancer diagnosis according to patient and tumor 
characteristics. Cancer Epidemiol Biomarkers Prev 21: 1792 1798, 2012. PMID: 22899730. DOI: 10.1158/1055-9965.epi-120674

24 Shen Y, Wang J, Han X, Yang H, Wang S, Lin D and Shi Y: Effectors of epidermal growth factor receptor pathway: the genetic profiling of KRAS, BRAF, PIK3CA, NRAS mutations in colorectal cancer characteristics and personalized medicine. PLoS One 8: e81628, 2013. PMID: 24339949. DOI: 10.1371/ journal.pone. 0081628

25 Yunxia Z, Jun C, Guanshan Z, Yachao L, Xueke Z and Jin L: Mutations in epidermal growth factor receptor and $\mathrm{K}$-ras in Chinese patients with colorectal cancer. BMC Med Genet 11: 34, 2010. PMID: 20184776. DOI: 10.1186/1471-2350-11-34

26 Liou JM, Wu MS, Shun CT, Chiu HM, Chen MJ, Chen CC, Wang HP, Lin JT and Liang JT: Mutations in BRAF correlate with poor survival of colorectal cancers in Chinese population. Int J Colorectal Dis 26: 1387-1395, 2011. PMID: 21553007. DOI: $10.1007 / \mathrm{s} 00384-011-1229-1$

27 Hsieh LL, Er TK, Chen CC, Hsieh JS, Chang JG and Liu TC: Characteristics and prevalence of KRAS, BRAF, and PIK3CA mutations in colorectal cancer by high-resolution melting analysis in Taiwanese population. Clin Chim Acta 413: 16051611, 2012. PMID: 22579930. DOI: 10.1016/j.cca.2012. 04.029

28 Shen H, Yuan Y, Hu HG, Zhong X, Ye XX, Li MD, Fang WJ and Zheng $S$ : Clinical significance of $\mathrm{K}$-ras and BRAF mutations in Chinese colorectal cancer patients. World J Gastroenterol 17: 809-816, 2011. PMID: 21390154. DOI: 10.3748/wjg.v17.i6.809

29 Liao W, Liao Y, Zhou JX, Xie J, Chen J, Huang W and Luo R: Gene mutations in epidermal growth factor receptor signaling network and their association with survival in Chinese patients with metastatic colorectal cancers. Anat Rec (Hoboken) 293: 1506-1511, 2010. PMID: 20652941. DOI: 10.1002/ar.21202

30 Mao C, Zhou J, Yang Z, Huang Y, Wu X, Shen H, Tang J and Chen Q: KRAS, BRAF and PIK3CA mutations and the loss of PTEN expression in Chinese patients with colorectal cancer. PLoS One 7: e36653, 2012. PMID: 22586484. DOI: 10.1371/ journal. pone.0036653

31 Natsumi I, Yoshifumi B, Katsuhiko N, Kaori S, Liying Y, Dora Dias-S, A. John I, Charles SF, Kevin MH and Shuji O: NRAS mutations are rare in colorectal cancer. Diagn Mol Pathol 19(3): 157-163, 2010. DOI: 10.1097/PDM.0b013e3181c93fd1

32 Fang G, Hai G, Huanhuan Z, Jing C, Yiming Z, Lihua Z, Aifeng $\mathrm{Z}$, Hui J, Jianqiong $\mathrm{Z}$ and Youji $\mathrm{H}$ : Mutation status and prognostic values of KRAS, NRAS, BRAF and PIK3CA in 353 Chinese colorectal cancer patients. Sci Rep 8: 6076, 2018. DOI: 10.1038/s41598-018-24306-1

33 NCCN Clinical practice guidelines in oncology. Colon Cancer. Version 2. Accessed: 2 June 2014. Available from: http:// www.nccn.org/professionals/physician_gls/pdf/ colon.pdf

34 Ribic CM, Sargent DJ, Moore MJ, Thibodeau SN, French AJ, Goldberg RM, Hamilton SR, Laurent-Puig P, Gryfe R, Shepherd LE, Tu D, Redston M and Gallinger S: Tumor microsatelliteinstability status as a predictor of benefit from fluorouracil-based adjuvant chemotherapy for colon cancer. N Engl J Med 349: 247-257, 2003. PMID: 12867608. DOI: 10.1056/NEJMoa 022289

35 Guastadisegni C, Colafranceschi M, Ottini L and Dogliotti E: Microsatellite instability as a marker of prognosis and response to therapy: a meta-analysis of colorectal cancer survival data. Eur J Cancer 46: 2788-2798, 2010. PMID: 20627535. DOI: 10.1016/j.ejca.2010.05.009

36 Malesci A, Laghi L, Bianchi P, Delconte G, Randolph A, Torri V, Carnaghi C, Doci R, Rosati R, Montorsi M, Roncalli M, Gennari L and Santoro A: Reduced likelihood of metastases in patients with microsatellite-unstable colorectal cancer. Clin Cancer Res 13: 3831-3839, 2007. PMID: 17606714. DOI: 10.1158/1078-0432.CCR-07-0366

37 Muller CI, Schulmann K, Reinacher-Schick A, Andre N, Arnold D, Tannapfel A, Arkenau H, Hahn SA, Schmoll SH, Porschen R, Schmiegel W, Graeven U and AIO Colorectal Study Group: Predictive and prognostic value of microsatellite instability in patients with advanced colorectal cancer treated with a fluoropyrimidine and oxaliplatin containing first-line chemotherapy. A report of the AIO Colorectal Study Group. Int J Colorectal Dis 23: 1033-1039, 2008. PMID: 18594845. DOI: 10.1007/s00384-008-0504-2

38 Tikidzhieva A, Benner A, Michel S, Formentini A, Link KH, Dippold W, von Knebel Doeberitz M, Kornmann M and Kloor M: Microsatellite instability and Beta2-Microglobulin mutations as prognostic markers in colon cancer: results of the FOGT-4 trial. Br J Cancer 106: 1239-1245, 2012. PMID: 22353804. DOI: 10.1038/bjc. 2012.53

39 Sargent DJ, Marsoni S, Monges G, Thibodeau SN, Labianca R, Hamilton SR, French AJ, Kabat B, Foster NR, Torri V, Ribic C, Grothey A, Moore M, Zaniboni A, Seitz JF, Sinicrope F and Gallinger S: Defective mismatch repair as a predictive marker for lack of efficacy of fluorouracil-based adjuvant therapy in colon cancer. J Clin Oncol 28: 3219-3226, 2010. PMID: 20498393. DOI: 10.1200/JCO.2009.27.1825

40 Amado RG, Wolf M, Peeters M, Van Cutsem E, Siena S, Freeman DJ, Juan T, Sikorski R, Suggs S, Radinsky R, Patterson SD and Chang DD: Wild-type KRAS is required for panitumumab efficacy in patients with metastatic colorectal cancer. J Clin Oncol 26: 1626-1634, 2008. PMID: 18316791. DOI: $10.1200 / J C O .2007 .14 .7116$

41 Karapetis CS, Khambata-Ford S, Jonker DJ, O'Callaghan CJ, Tu D, Tebbutt NC, Simes RJ, Chalchal H, Shapiro JD, Robitaille S, Price TJ, Shepherd L, Au HJ, Langer C, Moore MJ and Zalcberg JR: K-ras mutations and benefit from cetuximab in advanced colorectal cancer. N Engl J Med 359: 1757-1765, 2008. PMID: 18946061. DOI: 10.1056/NEJMoa 0804385.

42 Van Cutsem E, Kohne CH, Hitre E, Zaluski J, Chang Chien CR, Makhson A, D'Haens G, Pintér T, Lim R, Bodoky G, Roh JK, Folprecht G, Ruff P, Stroh C, Tejpar S, Schlichting M, Nippgen J and Rougier P: Cetuximab and chemotherapy as initial treatment for metastatic colorectal cancer. N Engl J Med 360: 1408-1417, 2009. PMID: 19339720. DOI: 10.1056/NEJMoa0805019.

43 Van Cutsem E, Kohne CH, Lang I, Folprecht G, Nowacki MP, Cascinu S, Shchepotin I, Maurel J, Cunningham D, Tejpar S, Schlichting M, Zubel A, Celik I, Rougier P and Ciardiello F: Cetuximab plus irinotecan, fluorouracil, and leucovorin as firstline treatment for metastatic colorectal cancer: updated analysis of overall survival according to tumor KRAS and BRAF mutation status. J Clin Oncol 29: 2011-2019, 2011. PMID: 21502544. DOI: $10.1200 / J C O .2010 .33 .5091$

44 Bokemeyer C, Bondarenko I, Makhson A, Hartmann JT, Aparicio J, de Braud F, Donea S, Ludwig H, Schuch G, Stroh C, Loos AH, 
Zubel A and Koralewski P: Fluorouracil, leucovorin, and oxaliplatin with and without cetuximab in the first-line treatment of metastatic colorectal cancer. J Clin Oncol 27: 663-671, 2009. PMID: 19114683. DOI: 10.1200/JCO.2008.20.8397

45 Bokemeyer C, Bondarenko I, Hartmann JT, de Braud F, Schuch G, Zubel A, Celik I, Schlichting M and Koralewski P: Efficacy according to biomarker status of cetuximab plus FOLFOX-4 as first-line treatment for metastatic colorectal cancer: the OPUS study. Ann Oncol 22: 1535-1546, 2011. PMID: 21228335. DOI: 10.1093/annonc/mdq632

46 Peeters M, Price TJ, Cervantes A, Sobrero AF, Ducreux M, Hotko Y, André T, Chan E, Lordick F, Punt CJ, Strickland AH, Wilson G, Ciuleanu TE, Roman L, Van Cutsem E, Tzekova V, Collins S, Oliner KS, Rong A and Gansert J: Randomized phase III study of panitumumab with fluorouracil, leucovorin, and irinotecan (FOLFIRI) compared with FOLFIRI alone as second-line treatment in patients with metastatic colorectal cancer. J Clin Oncol 28: 47064713, 2010. PMID: 20921462. DOI: 10.1200/JCO.2009.27.6055

47 Dudley JC, Lin MT, Le DT and Eshleman JR: Microsatellite instability as a biomarker for PD-1 blockade. Clin Cancer Res 22: 813-820, 2016. PMID: 26880610. DOI: 10.1158/10780432.CCR-15-1678

48 Le DT, Uram JN, Wang H, Bartlett BR, Kemberling H, Eyring AD, Skora AD, Luber BS, Azad NS, Laheru D, Biedrzycki B, Donehower RC, Zaheer A, Fisher GA, Crocenzi TS, Lee JJ, Duffy SM, Goldberg RM, de la Chapelle A, Koshiji M, Bhaijee F, Huebner T, Hruban RH, Wood LD, Cuka N, Pardoll DM, Papadopoulos N, Kinzler KW, Zhou S, Cornish TC, Taube JM, Anders RA, Eshleman JR, Vogelstein B and Diaz LA Jr: PD-1 Blockade in tumors with mismatch-repair deficiency. N Engl J Med 372: 2509-2520, 2015. PMID: 26028255. DOI: 10.1056/ NEJMoa1500596

49 Levidou G, Saetta AA, Gigelou F, Karlou M, Papanastasiou P, Stamatelli A, Kavantzas N, Michalopoulos NV, Agrogiannis G, Patsouris E and Korkolopoulou P: ERK/pERK expression, B-raf and K-ras mutations in colon adenocarcinomas: correlation with clinicopathological characteristics and expression of hMLH1 and hMSH2. World J Surg Oncol 10: 47, 2012. PMID: 22376079. DOI: $10.1186 / 1477-7819-10-47$

50 Sakellariou S, Fragkou P, Levidou G, Gargalionis AN, Piperi C, Dalagiorgou G, Adamopoulos C, Saetta A, Agrogiannis G, Theohari I, Sougioultzis S, Tsioli P, Karavokyros I, Tsavaris N, Kostakis I.D, Zizi-Serbetzoglou A, Vandoros G.P, Patsouris E and Korkolopoulou P: Clinical significance of AGE-RAGE axis in colorectal cancer: associations with glyoxalase-I, adiponectin receptor expression and prognosis, BMC Cancer 16: 174, 2016. PMID: 26931562. DOI: 10.1186/s12885-016-2213-5

51 Tsikalakisa S, Chatziandreoua I, Michalopoulos N, Theodoropoulos G, Sakellariou S, Korkolopoulou P, Patsouris E and Saetta A: Comprehensive expression analysis of TNF-related apoptosis-inducing ligand and its receptors in colorectal cancer: Correlation with MAPK alterations and clinicopathological associations. Pathol Res Pract 214: 826-834, 2018. PMID: 29731264. DOI: 10.1016/j.prp.2018.04.019

52 Abotchie PN, Vernon SW and Du XL: Gender differences in colorectal cancer incidence in the United States, 1975-2006. J Womens Health (Larchmt) 21(4): 393-400, 2012. PMID: 22149014. DOI: $10.1089 /$ jwh.2011.2992

53 Samowitz WS, Curtin K, Schaffer D, Robertson M, Leppert M and Slattery ML: Relationship of Ki-ras mutations in colon cancers to tumor location, stage, and survival: a populationbased study. Cancer Epidemiol Biomarkers Prev 9: 1193-1197, 2000. PMID: 11097226.

54 Brink M, de Goeij AF, Weijenberg MP, Roemen GM, Lentjes MH, Pachen MM, Smits KM, de Bruïne AP, Goldbohm RA and van den Brandt PA: K-ras oncogene mutations in sporadic colorectal cancer in The Netherlands Cohort Study. Carcinogenesis 24: 703-710, 2003. PMID: 12727799.

55 Gao J, Sun ZW, Li YY and Shen L: Mutations of KRAS and BRAF in Chinese patients with colorectal carcinoma: analyses of 966 cases. Zhonghua Bing Li Xue Za Zhi 41: 579-583, 2012. PMID: 23157823. DOI: 10.3760/cma.j.issn.0529-5807.2012.09. 002

56 Hanna MC, Go C, Roden C, Jones RT, Pochanard P, Javed AY, Javed A, Mondal C, Palescandolo E, Van Hummelen P, Hatton C, Bass AJ, Chun SM, Na DC, Kim TI, Jang SJ, Osarogiagbon RU, Hahn WC, Meyerson M, Garraway LA and MacConaill LE: Colorectal cancers from distinct ancestral populations show variations in BRAF mutation frequency. PLoS One 8: e74950, 2013. PMID: 24066160. DOI: 10.1371/journal.pone.0074950

57 Ye JX, Liu Y, Qin Y, Zhong HH, Yi WN and Shi XY: KRAS and BRAF gene mutations and DNA mismatch repair status in Chinese colorectal carcinoma patients. World J Gastroenterol 21(5): 1595-1605, 2015. PMID: 25663779. DOI: $10.3748 /$ wjg.v21.i5.1595

58 Seppälä TT, Böhm JP, Friman M, Lahtinen L, Väyrynen VM, Liipo TK, Ristimäki AP, Kairaluoma MV, Kellokumpu IH, Kuopio TH and Mecklin JP: Combination of microsatellite instability and BRAF mutation status for subtyping colorectal cancer. Br J Cancer 112: 1966-1975, 2015. PMID: 25973534. DOI: $10.1038 /$ bjc.2015.160

59 Zhu XL, Cai X, Zhang L, Yang F, Sheng WQ, Lu YM, Du X and Zhou XY: KRAS and BRAF gene mutations in correlation with clinicopathologic features of colorectal carcinoma in Chinese. Zhonghua Bing Li Xue Za Zhi 41: 584-589, 2012. PMID: 23157824. DOI: 10.3760/cma.j.issn.0529-5807.2012.09.003

60 Yunxia Z, Jun C, Guanshan Z, Yachao L, Xueke Z and Jin L: Mutations in epidermal growth factor receptor and K-ras in Chinese patients with colorectal cancer. BMC Med Genet 11: 34, 2010. PMID: 20184776. DOI: 10.1186/1471-2350-11-34

61 Liou JM, Wu MS, Shun CT, Chiu HM, Chen MJ, Chen CC, Wang HP, Lin JT and Liang JT: Mutations in BRAF correlate with poor survival of colorectal cancers in Chinese population. Int J Colorectal Dis 26: 1387-1395, 2011. PMID: 21553007. DOI: $10.1007 / \mathrm{s} 00384-011-1229-1$

62 Hsieh LL, Er TK, Chen CC, Hsieh JS, Chang JG and Liu TC: Characteristics and prevalence of KRAS, BRAF, and PIK3CA mutations in colorectal cancer by high-resolution melting analysis in Taiwanese population. Clin Chim Acta 413: 16051611, 2012. PMID: 22579930. DOI: 10.1016/j.cca.2012.04.029

63 Shen H, Yuan Y, Hu HG, Zhong X, Ye XX, Li MD, Fang WJ and Zheng S: Clinical significance of K-ras and BRAF mutations in Chinese colorectal cancer patients. World J Gastroenterol 17: 809-816, 2011. PMID: 21390154. DOI: 10.3748/wjg.v17.i6.809

64 Yanus GA, Belyaeva AV, Ivantsov AO, Kuligina ESh, Suspitsin EN, Mitiushkina NV, Aleksakhina SN, Iyevleva AG, Zaitseva OA, Yatsuk OS, Gorodnova TV, Strelkova TN, Efremova SA, Lepenchuk AY, Ochir-Garyaev AN, Paneyah MB, Matsko DE, Togo AV and Imyanitov EN: Pattern of clinically relevant 
mutations in consecutive series of Russian colorectal cancer patients. Med Oncol 30: 686, 2013. PMID: 23943423. DOI: 10.1007/ s12032-013-0686-5

65 Xu XM, Qian JC, Cai Z, Tang T, Wang P, Zhang KH, Deng ZL and Cai JP: DNA alterations of microsatellite DNA, p53, APC and K-ras in Chinese colorectal cancer patients. Eur J Clin Invest 42: 751-759, 2012. PMID: 22324744. DOI: 10.1111/j.13652362.2011.02641.X

66 Li HT, Lu YY, An YX, Wang X and Zhao QC: KRAS, BRAF and PIK3CA mutations in human colorectal cancer: relationship with metastatic colorectal cancer. Oncol Rep 25: 1691-1697, 2011. PMID: 21424126. DOI: 10.3892/or.2011.1217

67 Molinari F, Felicioni L, Buscarino M, De Dosso S, Buttitta F, Malatesta S, Movilia A, Luoni M, Boldorini R, Alabiso O, Girlando S, Soini B, Spitale A, Di Nicolantonio F, Saletti P, Crippa S, Mazzucchelli L, Marchetti A, Bardelli A and Frattini M: Increased detection sensitivity for KRAS mutations enhances the prediction of anti-EGFR monoclonal antibody resistance in metastatic colorectal cancer. Clin Cancer Res 17: 4901-4914, 2011. PMID: 21632860. DOI: $10.1158 / 1078-0432$.ccr-10-3137

68 Tan C and Du X: KRAS mutation testing in metastatic colorectal cancer.World J Gastroenterol 18(37): 5171-5180, 2012. PMID: 23066310. DOI: 10.3748/wjg.v18.i37.5171

69 Chan TL, Zhao W, Leung SY and Yuen ST; Cancer Genome Project: BRAF and KRAS mutations in colorectal hyperplastic polyps and serrated adenomas. Cancer Res 63: 4878-4881, 2003. PMID: 12941809.

70 Wójcik P, Okoń K, Osuch C, Klimkowska A and Tomaszewska R: BRAF mutations in sporadic colorectal carcinoma from polish patients. Pol J Pathol 61: 23-26, 2010. PMID: 20496269.

71 Hanna MC, Go C, Roden C, Jones RT, Pochanard P, Javed AY, Javed A, Mondal C, Palescandolo E, Van Hummelen P, Hatton C, Bass AJ, Chun SM, Na DC, Kim TI, Jang SJ, Osarogiagbon RU, Hahn WC, Meyerson M, Garraway LA and MacConaill LE: Colorectal cancers from distinct ancestral populations show variations in BRAF mutation frequency. PLoS One 8: e74950, 2013. PMID: 24066160. DOI: 10.1371/journal.pone.0074950

72 Umeda Y, Nagasaka T, Mori Y, Sadamori H, Sun DS, Shinoura S, Yoshida R, Satoh D, Nobuoka D, Utsumi M, Yoshida K, Yagi $\mathrm{T}$ and Fujiwara T: Poor prognosis of KRAS or BRAF mutant colorectal liver metastasis without microsatellite instability. J Hepatobiliary Pancreat Sci 20: 223-233, 2013. PMID: 23010994. DOI: $10.1007 /$ s00534-012-0531-9

73 Toon CW, Chou A, DeSilva K, Chan J, Patterson J, Clarkson A, Sioson L, Jankova $\mathrm{L}$ and Gill AJ: BRAFV600E immunohistochemistry in conjunction with mismatch repair status predicts survival in patients with colorectal cancer. Mod Pathol 27: 644-650, 2014. PMID: 24157612. DOI: 10.1038/ modpathol.2013.200

74 Li HT, Lu YY, An YX, Wang X and Zhao QC: KRAS, BRAF and PIK3CA mutations in human colorectal cancer: relationship with metastatic colorectal cancer. Oncol Rep 25: 1691-1697, 2011. PMID: 21424126. DOI: 10.3892/or.2011.1217

75 Phipps AI, Buchanan DD, Makar KW, Win AK, Baron JA, Lindor NM, Potter JD and Newcomb PA: BRAF mutation status and survival after colorectal cancer diagnosis according to patient and tumor characteristics. Cancer Epidemiol Biomarkers Prev 21: 1792-1798, 2012. DOI: 10.1038/bjc.2013.118

76 Parsons MT, Buchanan DD, Thompson B, Young JP and Spurdle $\mathrm{AB}$ : Correlation of tumour BRAF mutations and MLH1 methylation with germline mismatch repair (MMR) gene mutation status: a literature review assessing utility of tumour features for MMR variant classification. J Med Genet 49: 151157, 2012. PMID: 22368298. DOI: 10.1136/jmedgenet-2011100714

77 San-Gang Wu, Jia-Yuan Sun, Juan Zhou, Feng-Yan Li, Qin Lin, Huan-Xin Lin, Xun-Xing Guan and Zhen-Yu He: Number of negative lymph nodes is associated with disease-free survival in patients with breast cancer. BMC Cancer 15: 43, 2015. PMID: 25880737. DOI: $10.1186 / \mathrm{s} 12885-015-1061-\mathrm{z}$

78 Ribic CM, Sargent DJ, Moore MJ, Thibodeau SN, French AJ, Goldberg RM, Hamilton SR, Laurent-Puig P, Gryfe R, Shepherd LE, Tu D, Redston M and Gallinger S: Tumor microsatelliteinstability status as a predictor of benefit from fluorouracil-based adjuvant chemotherapy for colon cancer. N Engl J Med 349: 247-257, 2003. PMID: 12867608. DOI: 10.1056/NEJM oa022289

79 Guastadisegni C, Colafranceschi M, Ottini L and Dogliotti E: Microsatellite instability as a marker of prognosis and response to therapy: a meta-analysis of colorectal cancer survival data. Eur J Cancer 46: 2788-2798, 2010. PMID: 20627535. DOI: 10.1016/j.ejca.2010.05.009

80 Malesci A, Laghi L, Bianchi P, Delconte G, Randolph A, Torri V, Carnaghi C, Doci R, Rosati R, Montorsi M, Roncalli M, Gennari L and Santoro A: Reduced likelihood of metastases in patients with microsatellite-unstable colorectal cancer. Clin Cancer Res 13: 3831-3839, 2007. PMID: 17606714. DOI: 10.1158/1078-0432.CCR-07-0366

81 Muller CI, Schulmann K, Reinacher-Schick A, Andre N, Arnold D, Tannapfel A, Arkenau H, Hahn SA, Schmoll SH, Porschen R, Schmiegel W, Graeven U and AIO Colorectal Study Group: Predictive and prognostic value of microsatellite instability in patients with advanced colorectal cancer treated with a fluoropyrimidine and oxaliplatin containing first-line chemotherapy. A report of the AIO Colorectal Study Group. Int J Colorectal Dis 23: 1033-1039, 2008. PMID: 18594845. DOI: 10.1007/s00384-008-0504-2

82 Tikidzhieva A, Benner A, Michel S, Formentini A, Link KH, Dippold W, von Knebel Doeberitz M, Kornmann M and Kloor M: Microsatellite instability and Beta2-Microglobulin mutations as prognostic markers in colon cancer: results of the FOGT-4 trial. Br J Cancer 106: 1239-1245, 2012. PMID: 22353804. DOI: $10.1038 /$ bjc. 2012.53

83 Funkhouser WK Jr., Lubin IM, Monzon FA, Zehnbauer BA, Evans JP, Ogino S and Nowak JA: Relevance, pathogenesis, and testing algorithm for mismatch repair-defective colorectal carcinomas: a report of the association for molecular pathology. J Mol Diagn 14: 91-103, 2012. PMID: 22260991. DOI: 10.1016/j.jmoldx.2011.11.001

84 Setaffy L and Langner C: Microsatellite instability in colorectal cancer: clinicopathological significance. Pol J Pathol 66: 203218, 2015. PMID: 26619098.
Received September 25, 2019

Revised October 10, 2019

Accepted October 11, 2019 